Dalia Nassar*

\title{
The Human Vocation and the Question of the Earth: Karoline von Günderrode's Philosophy of Nature
}

https://doi.org/10.1515/agph-2019-0028

\begin{abstract}
Contra widespread readings of Karoline von Günderrode's 1805 “Idea of the Earth (Idee der Erde)" as a creative adaptation of Schelling's philosophy of nature, this article proposes that "Idea of the Earth" furnishes a moral account of the human relation to the natural world, one which does not map onto any of the more well-known romantic or idealist accounts of the human-nature relation. Specifically, I argue that "Idea of the Earth" responds to the great Enlightenment question concerning the human vocation, but from a distinctive romantic-idealist angle. I begin by demonstrating the influence of Fichte's 1800 Vocation of Humanity on Günderrode's thinking, which involves an investigation of both Fichte's text and Günderrode's critical response to it. I then turn to "Idea of the Earth" where I analyse Günderrode's understanding of nature and the self in light of her critique of Fichte, and thereby distinguish her position from Fichte's and from the position espoused by her fellow romantics and idealists. By reading "Idea of the Earth" alongside Fichte's text and Günderrode's remarks on it, this article sheds new light on both Günderrode's understanding and defence of Naturphilosophie - against Fichte's critique of it - and her distinctive contribution to romantic philosophies of nature.
\end{abstract}

\section{Introduction}

The idea of 'nature' and the question concerning the human place within the natural world were at the heart of the German romantic and idealist projects. In fact, recent research has argued that the philosophy of nature, far from being just one of their concerns, furnished the romantics and idealists with the basis of their epistemology and metaphysics, their philosophies of art and aesthetics,

\footnotetext{
*Corresponding author: Dalia Nassar, University of Sydney, Department of Philosophy, Sydney, New South Wales 2006, AU; dalia.nassar@sydney.edu.au
}

Ә Open Access. (C) 2021 Nassar, published by De Gruyter. (c) BY This work is licensed under the Creative Commons Attribution 4.0 International License. 
and their political and social philosophies. ${ }^{1}$ This research has also distinguished, albeit implicitly, two main ways in which romantic and idealist philosophies of nature conceptualize the relation between the human being and the natural world, between human freedom and natural necessity.

The first strand, which can be traced back to Spinoza's influence on romanticism and idealism, ${ }^{2}$ foregrounds metaphysics and epistemology, and regards questions concerning human freedom and the human vocation as secondary, in the sense that these questions are thought to be answered - even if only indirectly - through the metaphysical and epistemological investigations. This strand is best represented by Friedrich Schelling, who considered the philosophy of nature to be the starting point for a theory of knowledge and being and regarded moral insights as subservient to the latter. Thus, in his 1799 First Outline of a System of a Philosophy of Nature (Erster Entwurf eines Systems der Naturphilosophie), Schelling attempts to derive all of reality, including human consciousness, from the fundamental forces of nature. In this context, human subjectivity and freedom are understood as the highest and most complex manifestation of natural productivity (HKA 1/8, 31). ${ }^{3}$ Accordingly, human morality is neither the starting point nor the end-goal of philosophical inquiry, but is regarded as the conscious reflection of nature's unconscious activity. For this reason, questions concerning human freedom and the human vocation are not at the heart of Schelling's philosophy of nature. There is no explicit investigation of how the human being ought to act in relation to the natural world or of how human action can be detrimental to the latter. Furthermore, while it is not necessary to conclude (with some commentators) that Schelling's project implies a complacent approach to moral questions, some of his remarks tend in this direction. He writes, for instance, that

1 On the centrality of the philosophy of nature for the development of romanticism and idealism, see Richards, The Romantic Conception of Life, Beiser, German Idealism and Beiser, Romantic Imperative, especially chs. 9 and 10. On the connection between epistemological and metaphysical questions in romantic philosophy of nature, see Nassar, The Romantic Absolute and Steigerwald, 'Epistemologies of Rupture' (with specific reference to Schelling).

2 Beiser, in particular, emphasizes this legacy and its outcomes for romantic and idealist moral philosophies. See German Idealism, 583 f.; Romantic Imperative, ch. 10.

3 Or as Sebastian Gardner puts it: "Within Schelling's idealism, nature is treated in terms of idealist categories, and the a priori reflection which, he holds, establishes that Nature in the sense of natura naturans is infinite pure activity joins seamlessly with scientific enquiry, which reveals natural phenomena, from the most basic forces of light, electricity and magnetism up to the complex functions of natural organisms, to be stages belonging to a single unified process which culminates in - for it is directed towards - the coming-into-existence of self-consciousness." Gardner 2011, 91. 
moral acts are to be understood as nature (as the absolute) 'acting through me' $(S W 6,305) .^{4}$

The second strand of romantic and idealist philosophy of nature agrees that the human being is part of nature, but regards moral questions as primary. This strand emphasizes the need to realize (potentially unrealizable) moral ideals. ${ }^{5}$ In contrast to the first strand, which sees the human being as nature's realization, the second strand sees the human being as a being who must realize or transform nature. Friedrich von Hardenberg (Novalis) is exemplary in this regard. Speaking of poets, he writes: 'We are on a mission: we have been called to educate the earth [zur Bildung der Erde sind wir berufen]' (NS 2, 427 n32). He goes on to describe this education as a moral task: 'Nature will become moral. We are her educators - her moral tangents - her moral stimuli' (NS 3, $252 \mathrm{n} 73$ ). On this account, it is only by transforming nature so as to align it with (our) moral ends that nature can be complete. $^{6}$

There is no doubt that any attempt to categorize these authors fails to account for the nuances and complexities of their writings. Yet these two strands are representative of our current understanding of romantic and idealist conceptions of the human-nature relationship and the moral responsibility of human beings toward nature. They are not, however, exhaustive. The aim of this paper is to identify a third romantic-idealist response to the question concerning the relationship between the human being and the natural world - one that has been largely ignored, but which might be the most relevant strand today. It is the position articulated by Karoline von Günderrode (1780-1806) in her 1805 essay "Idea of the Earth (Idee der Erde)".

Günderrode, a published poet and playwright with some renown during her lifetime, first gained widespread recognition through the 1840 publication of Bettina von Arnim's Die Günderode, an epistolary text loosely based on the philosophical correspondence of the two women in the years immediately preceding Günderrode's death. ${ }^{7}$ The earnestness of the exchange between the women, and

4 Beiser concludes that Schelling's remark implies a complacent moral philosophy. See Beiser 2003, ch. 10.

5 Manfred Frank's interpretation of the romantics as good Kantians emphasizes this strand to a greater extent. The view here is that the romantics do not assume an original unity as the starting point of philosophical inquiry (or regard it as achievable), but posit it as a regulative ideal and thus regard it (to some extent) as a moral task. Frank 1997, 851-57. On the differences between Beiser and Frank, see Millán-Zaibert 2005.

6 On Novalis's moral understanding of nature, see Nassar 2013, ch. 3.

7 The spelling of Günderrode's name as Günderode in von Arnim's text may have been intentional, as a means of indicating editorial authority. The author also offers a different spelling of her own name (Bettine instead of Bettina). 
the sophisticated philosophical content of the letters, made Die Günderode particularly popular among American intellectuals such as Emerson and Margaret Fuller, who saw the text as a paragon of Platonic friendship. ${ }^{8}$

More recently, Günderrode's philosophical significance has been revived through the publication of her complete works in the early 1990s, which include a volume of notes on Kant, Fichte, Schelling, Schleiermacher, Hemsterhuis, Novalis and Friedrich Schlegel, among others, and the appearance of scholarly works that convincingly situate Günderrode within philosophical romanticism and idealism. ${ }^{9}$ Thus, we now know that Günderrode was an avid reader of philosophy, and that her poetic writings were inspired by the same philosophical questions and concerns that inspired romanticism and idealism. We also know that Günderrode wrote a number of philosophical essays, which were highly regarded by her contemporaries, but which she was unable to publish during her lifetime. ${ }^{10}$

This applies above all to "Idea of the Earth", an essay which Günderrode composed at the height of her engagement with philosophy. ${ }^{11}$ It was during this period that Günderrode composed lengthy commentaries on Schelling's writings on the philosophy of nature and took notes on Fichte's popular 1800 work Die Bestimmung des Menschen (The Vocation of Humanity). ${ }^{12}$ However, despite the fact

8 Fuller partially translated Die Günderode into English in 1840 under the title Correspondence of Fräulein Günderode and Bettine von Arnim. Although Fuller published her translation anonymously, in 1842 she wrote an essay on Die Günderode for Emerson's journal, The Dial.

9 See esp. Westphal 1993, Dormann 2004; and Ezekiel, 'Introduction', in Günderrode, Poetic Fragments.

10 Her philosophical prose pieces include "Idea of the Earth", "The Manes" and "An Apocalyptic Fragment”. "The Manes" was highly regarded by von Arnim, who published it in Die Günderode. "Idea of the Earth" was praised by its first reader, Friedrich Creuzer, who wrote in a letter to Günderrode from 1 December 1805: "It's been a long time since I've liked anything as much as I like your 'Idea of the Earth”. (Rohde 1896, 78) More recently, Westphal has argued that "Idea of the Earth" contains the 'kernel' of Günderrode's 'thinking about nature'. Westphal 1993, 99.

11 As noted above (note 10) "Idea of the Earth" has been regarded as one of Günderrode's most interesting and significant works from the beginning. Günderrode intended for this piece to be published along with her collection, Melete, before her death in 1806. However, the philologist Friedrich Creuzer (her married lover) halted publication following Günderrode's death, for fear that his affair would become common knowledge (he recognized himself in the figure of "Eusebio" in the play and the prose pieces accompanying it). Creuzer did not only suppress publication of these works, but also destroyed various versions of them. See Hille 1999, 119-121. Today we have two versions of "Idea of the Earth", one which is titled “To Eusebio (An Eusebio)" (in the form of a letter to the character Eusebio) while the other is titled "Idea of the Earth". Both are available in GSW, vol. 1 .

12 Günderrode first learned of Schelling's philosophy in the summer of 1804, but had known of Fichte well before then, mainly through her mother. She was familiar with Fichte's popular 
that Günderrode was working through both Schelling and Fichte shortly before writing "Idea of the Earth", scholars have focused on Günderrode's connection to Schelling, ignoring her interest in Fichte. Accordingly, "Idea of the Earth" has been read as a creative adaptation of Schelling's philosophy of nature. ${ }^{13}$ Indeed, Günderrode's claim that the earth is both ideal and real appears to coincide with Schelling's understanding of nature as infinite productivity (natura naturans) and the (apparently finite) material product (natura naturata). ${ }^{14}$ Similarly, her view that a fundamental polarity underpins nature's activity parallels Schelling's emphasis on the original duality of nature. ${ }^{15}$

There are, however, important elements in "Idea of the Earth" that do not map onto any Schellingian concerns or themes. Günderrode's view that the earth must be 'realized' and her claim that this realization depends on human (moral) activity carries echoes of Novalis's view that the earth must be 'educated' and distinguishes her from Schelling, who never directly considers the question of the human 'ought' in his philosophy of nature. ${ }^{16}$ Furthermore, the text appears

book, The Vocation of Humanity, soon after its publication 1800. The editor of Günderrode's collected works, Walter Morgenthaler, dates her notes on Schelling to 1804 and her notes on Fichte to sometime before 1804 , without however being able to date the latter with any more precision (GSW 3, 325-30).

13 Morgenthaler argues that the piece should be interpreted as part of Günderrode's interest in Schelling (GSW 3, 336). Similarly, Westphal interprets the text entirely in light of Günderrode's interest in Schelling (see Westphal 1993, 99-104). By contrast, Dormann contends that the work does not only address topics of the philosophy of nature but also ethical and aesthetic concerns. However, Dormann continues to interpret these aesthetic and ethical concerns from an entirely Schellingian framework, writing that for Günderrode the ethical should be understood in terms of chemical sympathies. Dormann 2004, 184-89.

14 In the Introduction to the First Outline, Schelling explains that 'nature' is both the productivity of nature and its (apparently finite) products (HKA 1/8, 46). In her notes on Naturphilosophie Günderrode writes that 'nature is an eternal activity, a self-producing product, an ever enduring becoming, for if it were a being, then its productive activity would be cancelled out by this completion [...].' (GSW 2, 364).

15 Günderrode speaks of the 'primal connection of both forces' of nature in her notes on Naturphilosophie, while in "Idea of the Earth" she describes life as the coming together of two forces (GSW 1, 446). In the First Outline Schelling argues that the view that nature is composed of two opposing forces is the "absolute hypothesis" of the philosophy of nature (HKA 1/8, 35).

16 Schelling alters his views on human freedom and its relation to nature in his 1809 essay, Philosophical Investigations into the Essence of Human Freedom and Related Matters. As Michelle Kosch explains, in his earlier writings, Schelling was a 'compatabilist' in that he regarded human freedom to be in complete accord with natural necessity - another way of stating that for Schelling the question of 'ought' was simply not a fundamental philosophical concern, because human freedom was identical to natural necessity. By contrast, as Kosch notes, in 1809 Schelling develops an 'incompatabilist' position, where freedom and natural necessity are regarded as 
to be addressing questions concerning the human vocation - questions which Fichte poses in The Vocation of Humanity and which Günderrode interrogates in her notes on Fichte's text. The fact that Günderrode is specifically concerned with the human being's relationship to the earth also brings her closer to Novalis and Fichte, both of whom regard the cultivation of nature to be fundamentally connected to the human (poetic) vocation.

Nonetheless, despite her proximity to Novalis and Fichte, Günderrode's account of the human vocation departs from theirs in ways that makes her a particularly interesting interlocutor for us today. According to Günderrode, the human vocation is not to transform the earth in order to make it more amenable to human moral goals, but it is to be transformed for the sake of the earth's own vocation.

The moral resonances in "Idea of the Earth" can, however, be easily missed. The notion that the earth must be 'realized' is difficult to understand, while Günderrode's remarks on transformation are part of a larger metaphysical account of the human relation to the earth, and can thus be interpreted as purely metaphysical claims rather than moral ones. However, if "Idea of the Earth" is read in light of Günderrode's notes on Fichte's The Vocation of Humanity, the moral underpinnings and motivations of the text can no longer be missed. In fact, what becomes clear is that Günderrode - more so than any of her idealist and romantic contemporaries - takes the idea, that the human being generally acts against the earth and that our moral task is to transform ourselves in order to act for the earth, very seriously. This, I will argue, is the meaning of the 'realized' idea of the earth: the earth can indeed only achieve its realization through us; however, we must first transform ourselves in order to enable this realization.

Accordingly, to fully grasp the argument and significance of "Idea of the Earth" it is necessary to read it alongside both Fichte's The Vocation of Humanity and Günderrode's notes on Fichte's text. This paper will proceed as follows: In Section 1, I begin with an examination of Fichte's conception of the self, followed by a consideration of Günderrode's challenge to this conception in Section 2. In Section 3, I then turn to Fichte's understanding of nature and the earth, before investigating Günderrode's challenge to Fichte in Section 4. Günderrode's two challenges to Fichte in her notes become, I argue, key themes in "Idea of the Earth". In Section 5, I turn to "Idea of the Earth", homing in on the meaning and implications of Günderrode's claim that the earth must be 'realized'.

opposed. See Kosch, Freedom and Reason, esp. 113-15. As I see it, Günderrode is in some ways closer to the later Schelling than to the earlier one, given her emphasis on the human vocation and need for self-transformation. 


\section{Fichte's Conception of the Self in Vocation of Humankind}

Fichte wrote The Vocation of Humanity as a popular text, with the goal of bringing his philosophy to a wider audience and enabling his readers to better grasp the idea that underpins his philosophy, namely the summons to produce the fundamental acts of the self for oneself. Fichte had emphasized this idea in earlier works, especially in his two introductions to the Wissenschaftslehre from 1797, where he calls upon his readers to investigate their own process of reflection and in this way gain a different kind of insight into themselves. In The Vocation of Humanity, by contrast, the reader is invited to participate in an internal dialogue - an internal drama of sorts - in which the speaker critically assesses and dismisses various systematic attempts to grasp the self, arriving, finally, at the only portrayal of the self that can adequately account for human freedom.

Fichte's text comprises three books, which deal with doubt, knowledge, and faith respectively. As it is in the first and final books that Fichte takes up the question of the relation between the human being (and human freedom) and the natural world most directly, I will focus on these two parts.

Book 1 begins by the speaker raising the question the question "what is my vocation?" and coming to realize that what he regarded as his vocation was something that was given to him by education, society, etc. rather than determined by himself. He begins by asking who or what he is, and to respond to these questions he brackets all previous knowledge, claiming that he will "honestly accept the result whatever it may be" ( $B d M, 7 ; V o M, 3)$. In the end, however, he does not honestly accept the result of this self-examination, because its conclusions are "unbearable" and can only lead to "despair (Verzweiflung)" (BdM, 65; VoM, 33).

Before we consider what these conclusions are, let us turn to the account of the self that is developed in this first book. According to Fichte, the first examination of the self leads us to conceive of the self as part of a larger whole, namely nature. This means that to understand the self we must understand nature. At first sight, we are told, nature appears to be a chain of causes and effects, "in which every link is determined by that which has preceded it, and in its turn determines the next" ( $B d M, 14 \mathrm{f}$; VoM, 7). However, the speaker continues, this conception of nature does not account for the forms of things: what makes a flower a flower, for instance, cannot be explained by external, antecedent causes or, as Fichte puts it, "mere passivity [Leiden]" (BdM, 18; VoM, 8). There must be something in nature that enables things to achieve their distinctive forms. This capacity, we are told, must be internal rather than external and active rather than passive. Thus, the speaker arrives at the notion of "formative powers [bildende Kräfte]", picking up 
on the language developed by Blumenbach and adopted by Schelling and other philosophers of nature (BdM, 21; VoM, 10). ${ }^{17}$

Following Blumenbach, ${ }^{18}$ the speaker describes these formative forces as the means by which to explain how organic beings maintain their distinctive forms (their form as plant, as animal, or as human) over time (both individually and as a species). Importantly, and again following Blumenbach, the speaker notes that these forces cannot be gleaned with the physical eye. For they are the posited or assumed (and thus invisible) causes of visible effects, i.e., living beings: "I can describe this power only through its effects, and it is to me no more than the producing cause of such effects”. (BdM, 21; VoM, 10)

Now, although all living beings are underpinned by formative forces, the speaker continues, these forces must differ in different beings, corresponding to their distinctive forms and capacities. The human being thus possesses not only the formative power of the plant and the motive power of the animal, but also a thinking power:

I, like the plant, am a particular mode or manifestation of the formative-power; like the animal, a particular mode or manifestation of the power of motion; and besides these I am also a particular mode or manifestation of the thinking-power, and the union of these three original powers into one - into one harmonious development - is the distinguishing characteristic of my species. (BdM, 29f.; VoM, $14 \mathrm{f}$.)

However, the speaker continues, the fact that the self is a member of nature - an expression of a natural force - implies that the self is not self-grounding, but grounded in something outside of itself. This implies that it is not free. For who I am, how I behave, what I choose, are not determined by my will or intention,

17 Blumenbach introduces the notion of a Bildungstrieb (formative drive) in an essay titled "Ueber den Bildungstrieb," which he first published in 1780 in the Göttignisches Magazin der Wissenschaft und Litteratur. He published it as a monograph in 1781. Über den Bildungstrieb und das Zeugungsgeschäfte (Göttingen: Dietrich, 1781). Kant cautiously lauds Blumenbach's notion in the Critique of the Power of Judgment, while Schelling argues that Bildungstrieb is a foundational notion for the philosophy of nature (HKA 1/6, $217 \mathrm{f}$.). For a useful overview of the idea of Bildungstrieb in the philosophy of nature, see Richards, The Romantic Conception of Life, Chapter 5.

18 In Über den Bildungstrieb, Blumenbach invokes the Newtonian idea of a 'qualitas occulta' when speaking of the Bildungstrieb. He writes: 'I hope it will be superfluous to remind most readers that the word Bildungstrieb, like the words attraction, gravity, etc. should serve, no more and no less, to signify a power whose constant effect is recognized from experience and whose cause, like the causes of the aforementioned and commonly recognized natural powers, is for us a qualitas occulta...' Blumenbach, Über den Bildungstrieb, $25 \mathrm{f}$. Blumenbach was not the only eighteenth-century life scientist to make use of Newton's idea of occult qualities. See Wolfe, 'On the Role of Newtonian Analogies in Eighteenth-Century Life Science'. 
but by external circumstances (BdM, 33f.; VoM, 17). Such a conception of the self, Fichte contends, denies me all action and thus any possibility of a moral self: "I do not act at all; it is nature that acts through me [...]. I am not the author of my own being, but nature has made me myself, and all that I am' (BdM, 49; VoM, 25).

Fichte claims that this perspective "contradicts the profoundest aspirations, wishes and wants of my being" ( $B d M, 51 ; \operatorname{VoM}, 26)$. For it "contradicts all the purposes for which alone I live, and without which I should loathe my existence". The realization that who I am and how I act are out of my hands results in "horror" (BdM, 53; VoM, 27). The horror, in other words, comes from the realization that an externally-determined self is not a free self; in fact, it is no self at all.

With this conclusion, Fichte appears to be levelling a challenge at Schelling's understanding of nature and of the self's relation to and place within nature: a challenge based on moral concerns. While Günderrode is sympathetic to Fichte's moral intentions she does not think that he successfully challenges Schelling, or that his alternative account adequately portrays the complexity of the human relation to the natural world.

\section{Günderrode's First Challenge to Fichte}

In her notes, Günderrode follows Fichte's account of nature, his understanding of the formative forces, and his portrayal of the self within nature. She does not, however, follow his critical assessment of Naturphilosophie, nor does she agree that this account results in an elimination of the self. Instead, she emphasizes the value of seeing myself as part of a larger whole (i.e., nature), claiming that it is only by being part of this whole that I become a self.

To begin with, she notes that determination (Bestimmung) is only possible in relation to the whole: "That I am this and nothing else is necessarily determined in conjunction with the whole" (GSW 2, 290).$^{19}$ Such determination does not, however, imply the elimination of the self. Rather, it is only by being with others that the self comes to realize its limits and - through these limits - recognizes its individuality. As Günderrode puts it: "Because I am therefore only a part of being overall, and because there are multiple beings that are not me, I become conscious of my own being in its circumscribed state, which emerges through the being of the other beings'. These others are, importantly, concrete others, such

19 Unless otherwise specified, the English translation of Günderrode's works referred to here are by Anna Ezekiel and are forthcoming in the volume, Women Philosophers of the Long Nineteenth Century: The German Tradition, ed. D. Nassar/K. Gjesdal. 
that the limits that they impose upon me are real limits - limits which enable me to recognize how I am at once like and unlike them. In fact, it is the specificity and reality of these limits that enable me to recognize myself not as an abstract or pure I, but as my self. As she puts it, in recognizing myself as one of the many possible expressions of humanity I become "known to myself as my self" (KvG's emphasis). Günderrode's claim is that to be a self is to recognize one's self as one's self - not to regard one's self abstractly as a formal principle or a pure I. This means that to be a self is to be a concrete, real individual - something that can only be achieved through interacting with other real individuals. Here then we see Günderrode's first divergence from the view Fichte develops in Book 1.

This divergence follows from Günderrode's critique of Fichte's understanding and treatment of nature at large. His claim is that the self cannot be a member of nature, because that would undermine its self-grounding character. Yet this conclusion follows neither from the account of nature that Fichte himself offers nor from the account that is developed in contemporary philosophies of nature (i.e., Schelling's).

As we have seen, Fichte argues that nature is a formative power and that the human species exhibits a thinking power that distinguishes it from other species. Such an account appears closely aligned with Schelling's understanding of nature, where nature is regarded as a nexus of dynamic and developing forces, and natural products are finite manifestations of these dynamic forces. Through ongoing development, these products achieve increasing consciousness and, ultimately, in the form of the human being, freedom. Thus, seen from a Schellingian perspective, nature is not opposed to human freedom, but the source of it.

Schelling's key claim is that nature exhibits the very same structure of self-determination that underpins the $\mathrm{I}^{20}$ This structure becomes self-conscious in the human being and thus becomes an expression of freedom. ${ }^{21}$ In this way, nature achieves freedom in the human being. What is important to emphasize is that, for Schelling, the structure of self-determination that Fichte locates in the self is more originally the structure of organized beings. On Schelling's account,

20 Thus Schelling famously writes in the concluding remarks to his 1797 introduction of Ideen "Nature should be visible spirit, spirit should be invisible nature". $S W 1 / 2,56$.

21 This is the thesis of Schelling's System of Transcendental Idealism, which, in a letter to Schelling, Fichte claims to have read. In their letter exchange from this period, Fichte disputes the fundamental premise of the philosophy of nature, and argues instead that all we can know are the laws of our intelligence (SFB, 176). For Fichte nature can never be the starting point of inquiry. Fichte's elaboration of a philosophy of nature akin to Schelling's and his attempts to contest it (on practical grounds) in The Vocation of Humanity can thus be read as his public reply to Schelling. 
freedom is not opposed to nature, precisely because nature exhibits structures of self-determination, such that human self-determination can be understood as a more complex, conscious, and thus free, manifestation of these very structures.

Fichte perfectly understood the notion of nature as a dynamic unity of self-determining beings when he distinguished the view of nature as 'mere passivity' from the view of nature as composed of formative forces. In fact, one could argue that Fichte adopts the idea of a self-determining being that is both cause and effect of itself from the emerging life sciences and their attempt to describe living beings. ${ }^{22}$ However, when criticizing the conception of the self that emerges out of Naturphilosophie, Fichte reverts to the first elaboration of nature that he offers, i.e., of nature as a chain of 'rigid necessity' based purely on external efficient causality (BdM, 49; VoM, 25). For his claim is that by understanding myself as part of nature, I necessarily end up with a notion of a self that is not capable of self-determination. This conclusion only holds, however, if one regards nature as not self-determining. After all, from a Schellingian perspective, where nature exhibits a minimal form of self-determination, it does not follow that by regarding the self as part of nature I eliminate its self-determination. The opposite is in fact the case, i.e., it is as a member of nature that the self is able to achieve self-determination. Accordingly, Fichte's conclusion that a self that is part of nature is not self-determining must rest (even if only implicitly) on the view that nature lacks self-determination. ${ }^{23}$

A nature that lacks internal determination would certainly have no place for anything like a self-directing or self-causing entity, such as the I. Such a nature would, however, also have no place for any self-directing or self-causing entity, whether it be plants or animals. In other words, the conception of nature that Fichte invokes to challenge a vaguely Schellingian account of freedom in nature, which fails to account for the self-organizing processes of plants and animals, does not cohere with either Schelling's understanding of nature or with the account that Fichte himself had developed earlier in the text. From this it appears that Fichte does not properly take up and challenge the conception of freedom in nature that Schelling develops.

22 In Kant's Organicism, Mensch has shown that Kant's understanding of reason originates in his study of the life sciences and specifically the theory of epigenesis (which argues that organized beings emerge out of unformed matter that has the capacity to self-form). See Mensch 2013, 99-113. The argument could be extended to claim that Fichte's conception of self-consciousness as an original act in which the self as subject and the self as object has its sources in the description of living beings as self-organizing.

23 Fichte writes: "the reference of my being, and of all the determinations of my being, to a cause lying outside of myself [...] this is that from which I so violently recoiled" (BdM, 53; VoM 27). 
Günderrode is fully aware of the shortcomings of Fichte's challenge and her choice to dismiss his conclusions and assert their opposite makes this evident. She claims that the self can only emerge if it is a member of nature, a part of a larger whole, and she does not think there is anything logically inconsistent or morally abhorrent about this view, given that nature itself exhibits organization or self-direction.

A serious challenge to Schelling would have to take on the specific conception of freedom that he develops, i. e., his modelling of self-determination on the cause-effect structure found in organized beings - something which Fichte does not do here, but which he attempts to do in the third book of The Vocation of Humanity. In her notes on this third book, Günderrode appears more sympathetic to Fichte's critique, and with good reason. For she agrees with Fichte that any consideration of the human-nature relation must have a moral angle: it must allow the self to reflect carefully about how its actions may or may not be beneficial to nature, something that Schelling's early writings do not explicitly explore. Nonetheless, Günderrode's agreement with Fichte is contingent upon her distinctive conception of the self - or more accurately, her understanding of the self as both part of a larger, transforming reality, and as bearing a special moral responsibility toward this reality.

\section{Fichte on Human Freedom}

Having argued in Book 1 that nature is not the space in which human freedom can develop, in Book 3 Fichte elaborates the view of nature as a space of rude unfreedom that must be transformed in order to accord with human ends ( $B d M, 223$; $V o M, 116)$. This is imperative, he argues, because it is only by cultivating nature that we can achieve our vocation (BdM, 224f.; VoM, 116f.).

Although Fichte appears to emphasize the need to transform the earth to accommodate human morality, he goes on to argue that the human vocation cannot in fact be fulfilled on the earth. Rather, he maintains that it is only in a super-sensible realm (das Überirdische) that human freedom can be properly practiced. As he puts it, on the earth "there is no true freedom for us, no freedom which holds the ground of its determination absolutely and entirely within itself. Our freedom is, at best, that of the self-forming plant” (BdM, 280; VoM, 146). From this statement, it is clear that Fichte once again challenges the conception of freedom put forward by philosophers of nature such as Schelling. In contrast to his earlier challenge, however, Fichte now specifically claims that the activity of self-formation that occurs in nature is different in kind from human freedom. 
Accordingly, human freedom cannot in any way be regarded as similar to the self-formation we witness in plants, even if (following Schelling) human freedom is understood to be a more complex and conscious instantiation of that activity. Fichte's challenge is based on the claim that human freedom is not of the earth and thus requires that we posit a super-sensible realm.

To begin with, it is important to note that, according to Fichte, the super-sensible is not elsewhere: "the super-sensible world is no future world; it is now already present" (BdM, 271; VoM, 141). Nonetheless, he does think that the move to the super-sensible requires "the renunciation of the earthly [Verzichtleistung auf das Irdische]" (BdM, 278; VoM, 145). As we shall see, his argument can only work if the super-sensible is in fact elsewhere, i.e., if there is an ontological difference between the earthly realm and the super-sensible.

Fichte offers several justifications for the need to posit something beyond the earth. Since, I think, only two of them make sense, I will focus on these. ${ }^{24}$ The first justification appeals to the fact that I, as a reasonable being, set myself a purpose that I seek to achieve through will and determination. I must expect this purpose to be realizable, for otherwise I would not set it. However, if my goal is to achieve moral ends, by following the voice of conscience, I quickly realize that this goal is not achievable in the world of sense. It is possible that my moral intention does not achieve the goal I had intended (a moral act can have immoral consequences). Given my sensible existence, my intention can be easily hindered or transformed by external causes beyond my control. However, as a rational being who sets and seeks to achieve ends, I must assume that my will can be realized. Accordingly, I am required to posit a super-sensible realm in which my moral ends are realizable.

The second argument that Fichte offers is as follows: if it were the purpose of our existence to produce an "earthly condition of our race", then all we would need to be is "an unerring mechanism" whose actions achieve pre-determined goals

24 Fichte's first argument (which, I think, is not successful) begins by describing a utopic vision of life on earth, in which strife is eliminated and humanity lives (with nature) in a state of eternal peace and harmony. However, Fichte notes that if this is the purported goal of earthly life, it is finite (because it is achievable) which means that upon achieving it, human activity would lose all purpose (BdM, 246f.; VoM, 127). For this reason, Fichte goes on to argue that there must be a higher, non-earthly goal that grants meaning to human existence. This argument does not cohere with Fichte's premise in the Wissenschaftslehre (that the goal of human achievement is infinite) or with what he says later in The Vocation of Humanity (that it is impossible to achieve moral ends on earth). On the tension between this argument and the Wissenschaftslehre, see Farr 2013, 299. On contradictions in Fichte's arguments within this text, see Steinberg in Breazeale/ Rockmore (eds.) 2013, 65. 
(BdM, 254 f.; VoM, 132). However, the fact that I am capable of consciously choosing the moral good requires that I posit a non-mechanical, i.e., super-sensible realm, in which this freedom would make sense. As Fichte puts it,

there is something in me and there is something required of me, which finds in this life nothing to which it can be applied, and which is entirely superfluous and unnecessary for the attainment of the highest objects that can be attained on earth. There must therefore be a purpose in human existence which lies beyond this life. (BdM, 263 f.; VoM, 137)

In both cases, Fichte claims that the fact of reason and the fact of freedom demand that we move beyond the earth and posit a super-sensible realm: since reason and freedom are self-grounding, they cannot have their source in the sensible world, where everything is caused by something else. However, it is not only their source that is non-earthly, but also their realization, because it is only in the super-sensible that rational ends and free will are not impeded. In such a sphere, there is no separation between will and its consequence; because will is the only cause, nothing can hinder its realization.

Fichte's argument in Book 3 appears to be falling back on a mechanical conception of nature and, thus, once again to fail to address Schelling's conception of freedom. There is, however, an important difference between the argument he is launching here and the one developed in Book 1: Fichte now claims that human freedom cannot be realized on earth. For this reason, we must posit a super-sensible realm. Thus, his new challenge to the philosophy of nature is based on his introduction of the super-sensible, such that its success depends on the success of his justification of the super-sensible. The two arguments which I have reviewed depend on one key claim which remains, I think, largely implicit. It is the claim that self-determination requires the complete determination of the self, wherein nothing impedes the human will. For it is on the basis of this claim that Fichte is able to make two claims: that self-determination cannot be achieved in the sensible world, where it faces impediments, and that a non-sensible world must be posited..$^{25}$ Thus, the success of Fichte's argument depends on his claim that the will can only be realized in the super-sensible. This means that, despite his insistence on the contrary, Fichte creates two worlds: a world in which the will is realizable and a world in which it is not.

25 Fichte describes the properly free will as follows: "a will which operates purely as will; by itself, and absolutely without instrument or sensible material of its activity; which is, at the same time, both act and product; with whom to will is to do, to command is to execute; in which therefore the instinctive demand of reason for absolute freedom and independence is realized [...]' (BdM, 290; VoM, 151). 


\section{Günderrode's Second Challenge to Fichte}

In her notes, Günderrode homes in on the need to posit a super-sensible or spiritual world. Achieving one's moral vocation, she writes, requires belief in the spiritual, because "in the sensory world my free obedience does not work directly towards the command of duty; no[,] only an act can work, no matter what attitude it occurs with" (GSW 2, 295). This insight, she continues, "drives me to the belief in the spiritual world, where my spirit can work immediately, i.e., by mere will” (GSW 2, 295). Interestingly, Günderrode is not claiming - with Fichte that the spiritual is the only space in which my will can be realized. Rather, she claims more specifically that the spiritual is the space in which the will can work immediately. Accordingly, my will can be mediately or indirectly realized in the sensory world, i.e., on the earth rather than beyond it. ${ }^{26}$ Günderrode does not make the stronger claim that the will can only be realized in the spiritual world, because - unlike Fichte - she is not launching a challenge to the philosophy of nature. In fact, she goes on to identify the will not only with human freedom, but with the activity of animals and plants as well.

The question remains, however, as to why Günderrode posits the super-sensible at all. The answer, I think, can be found in a footnote, where Günderrode introduces the idea of opportunity. She writes: "My best will does not work in the world if I do not have the opportunity to show it in acts; if I do not have this opportunity, what is it worth, if there is only a sensory world?" (GSW2, 295, note). While Fichte argued for the necessity of the super-sensible on the basis of the separation between will and consequence, Günderrode posits the super-sensible because the sensible does not furnish me with the opportunity to realize my intention. Günderrode is pointing to the possibility of finding oneself in a situation in which one cannot even attempt to realize one's intention - a problematic far more basic than the separation of will and consequence. For Günderrode, this scenario was of course not simply imagined, but speaks of the reality of being a woman intellectual in the late eighteenth and early nineteenth centuries. Thus, on her view, insofar as it concerns opportunity, the spiritual provides a normative space in which I do not realize my will, but imagine a reality that offers me

26 This perspective is also evident in Günderrode's other writings, which investigate the possibility of action within a particular social and political context (rather than conceiving of our activity within nature more generally). In those writings (including her plays Muhammad, Hildgund and Magic and Destiny) she does not overlook the constraints of these contexts (in fact, she emphasizes them, as she does in the footnote to her notes on Fichte - see below) but she nonetheless maintains the importance of attempting to realize these ends, even if only partially, in the world (rather than beyond it). 
the opportunity to realize it. In other words, the spiritual furnishes me with a normative ideal of what the world ought to look like, in order to provide me with the opportunity to realize my will. On this account, the spiritual is not a different world, nor is it the space in which my will is realized. It is, rather, the ideal which I posit as necessary for my continued moral striving, or my transformation, in this world.

To some extent, this is in line with Fichte's position. Unlike Fichte, however, Günderrode does not oppose the spiritual and the earthly. For her, the earthly is a manifestation of the spiritual that allows us to realize moral ideals, such that our moral striving does not require us to "give up on the earth". One can mistake this for Fichte's view, given that he describes the will as "the common mediator [Vermittler] between us all" (BdM, 294; VoM, 152). When we look more closely, however, it becomes evident that for Fichte, "the common denominator between us all”, i. e., the will, specifically applies to human beings, to the exclusion of other beings (and indeed it must, if his challenge to the philosophy of nature is to succeed). For, Fichte explains, the acts of human beings differ from those of all other beings in that they "are not brought about by the mere mechanism of nature, but by a free will elevated above all nature" (BdM 297 f.; VoM, 155).

In deep contrast to Fichte, Günderrode contends that nature as a whole expresses a will, in other words, that all natural beings are self-directed in some way:

I am related to that will and everything around me is related to me. And its life is (as well as I can grasp) a self-forming and presenting willing that flows through the whole universe in manifold forms. A force that organizes itself in the plant, moves in the animal, and presents its own world in each. (GSW 2, 297)

In this passage, Günderrode conceives of the will not as a distinctively human capacity, but as a natural capacity - recalling the notion of formative forces that Fichte introduced in Book $1 .^{27}$ What she disagrees with is Fichte's claim that the capacity to transform one's self, in willing, is specifically human and allows one to rise "above all nature”. Her claim, ultimately, is that the will underpins all of reality, such that all beings are self-transforming, self-directed in some way.

27 Fichte appears to be challenging his distinctions, just a few pages later, when he writes that the will is "the creator of the world", and goes on to disagree with those "who regard the will as building up a world of an everlasting inert matter, which must remain inert and lifeless [...]' (BdM, 302; VoM, 157) - the implication being that the will animates the world in its entirety, such that nothing in it is inert or lifeless. Thus, Fichte here seems to affirm rather than challenge a unity between the earthly and that which he designates as beyond the earth. 
She does, however, note a difference between human willing and other forms of willing - a difference that has to do with our particular ability to consciously seek to transform ourselves. It is, ultimately, this ability that sets us apart and bestows us a special responsibility towards the earth.

\section{Idea of the Earth}

"Idea of the Earth" was written in 1805, a year or so after Günderrode commented on Fichte's The Vocation of Humanity. ${ }^{28}$ While the themes of the essay are ones that Günderrode considers in other contexts as well, in "Idea of the Earth" she focuses on the question of the relation of the human being to the earth from a moral perspective - a perspective which can be easily missed if not read alongside her notes on Fichte.

To begin with, Günderrode remarks that the earth is constantly transforming, and indeed striving. As such, the earth appears to be directed toward a specific goal, which Günderrode describes as the 'realization' of the 'idea' of the earth (GSW 1, 446). To speak of the earth as an idea that strives may seem strange at first sight, for it implies that the earth is not only a material reality, but also an ideal reality. In light of Günderrode's notes on Fichte, however, the conception of the earth as an ideal or spiritual reality gains some clarity. ${ }^{29}$ On the one hand, Günderrode is drawing on the notion of formative force, which Fichte discusses in Book 1. As noted above, these forces cannot be seen with the physical eyes (they are a qualitas occulta). All that we can see are their effects (e.g., the activities of living beings). In her notes on Fichte, Günderrode further developed the conception of formative power by connecting it to the will. Or, as she puts it in "Idea of the Earth":

The earth is a realized idea, a simultaneously effecting (force [Kraft]) and an effect (appearance [Erscheinung]). [It is] thus a unity of soul and body, the latter [is one] pole of her activity in which she [the earth] turns outward and which we call existence, form, body; the former is turned inward [and we call it] intensity, essence, force [Kraft], soul. (GSW 1, 446)

28 See note 12 above.

29 While we could also draw on Schelling to interpret Günderrode here, Günderrode diverges from Schelling on this important point - and, I believe, comes much closer to Fichte. As Ruth Christmann has noted, Günderrode's emphasis on striving toward a final goal distinguishes her from Schelling, who instead focuses on the original duality that makes possible nature's infinite productivity. Cf. Christmann 2005, 112. 
On the other hand, Günderrode works with the view - also developed in her notes - that the ideal or spiritual places a normative claim upon us, a claim that calls for the transformation of the earth and ourselves. The earth, she writes, must be 'realized' (GSW 1, 447), and as members of the earth's "communal organism [gemeinschaftlichen Organismus]" it is our task to help bring this about (GSW 1, 448; translation modified). The earth, and our relation to it, thus places a normative claim upon us, and it is our task to understand what this claim requires and to act accordingly.

Günderrode explains that all members of the earth's community "give back to the earth", i. e., contribute something to the earth's realization. This contribution involves transformation. In one sense, this transformation is metaphysical or ontological, insofar as all living beings transform (this is what it means to be alive). But in another sense, this transformation is moral. For, Günderrode maintains, in the case of the human being, 'giving back' involves a conscious form of transformation, where we are being called upon to transform ourselves. Specifically, we are called upon to transform the way we think and feel, the way we perceive and understand, such that what appears to be distinct (mind and body, self and other, sensation and cognition) begins to appear as one. As Günderrode puts it, the realization of the earth requires us to bring about the unity between "being (body) and thought (spirit)" to such an extent that they "penetrate one another" and become "indistinguishable" (GSW 1, 448). ${ }^{30}$

While this may strike us as highly speculative, Günderrode's claim is that human beings experience a separation between inner and outer, self and world, self and others. ${ }^{31}$ This separation is, however, false. It is metaphysically false insofar as the human self is fundamentally relational. As she put it in her notes on Fichte: "That I am this and nothing else is necessarily determined in conjunction with the whole" (GSW 2, 290). Accordingly, our experience of separation or our sense of ourselves as isolated and self-grounding misrepresents the reality of the self and its relation to the world. It is, in turn, the human being's special task to transform herself so as to become more aligned with this reality. Günderrode describes this self-transformation as achieving 'unity' with oneself.

Fichte too had argued that self-unity is the highest goal of humanity. Fichte, however, conceives of self-unity as the formal unity of the self with its pure I,

30 She further writes that the goal is to arrive at a state in which "body [Körper] is simultaneously spirit, thought is simultaneously body [Leib]" (GSW 1, 448).

31 In "Idea of the Earth" Günderrode does not conceive of others in specifically anthropocentric terms, i.e., as human others, but rather as members of the "communal organism" that is the earth (GSW 2, 448). Thus, 'others' in this context always refers to both human and non-human others. 
which he identifies with self-determination. As he puts it in Some Lectures Concerning the Vocation of the Scholar (1794): “The human being is always supposed to be at one with itself; it should never contradict itself." Precisely because the pure I "is always one and the same”, this goal, Fichte explains, only obtains for the empirical I, which does contradict itself. Accordingly, the goal of the empirical I must be "to determine itself and not permit itself to be determined by something foreign". This implies that the fundamental principle of morality "is to act so that you could consider the maxims of your willing to be eternal laws for yourself". ${ }^{32}$

This conceptualization of self-unity follows from Fichte's understanding of the self as absolutely self-grounding, which entails that the self cannot emerge through its relations with others, but that others emerge out of the self. As he puts it in The Vocation of Humanity: "The ground upon which I assume the existence of something beyond myself does not lie outside of myself, but within me, in the limitation of my own personality". It is thus from myself (and more specifically from my limitation) that I can go on to make an 'inference' with regard to the existence of others ( $B d M, 41 ; V o M, 20)$. In light of this, it appears that the self precedes and makes possible my relation to others. Furthermore, the goal of selfunity, which he describes as unity of the empirical I with the pure I, specifically addresses unity with one's self - not unity with others.

As we have seen, for Günderrode, the self emerges only through being with others, such that others are not secondary to the self, but are at its very foundation. Accordingly, her conception of unity and harmony with one's self significantly differs from Fichte’s. To achieve ‘unity’ or ‘harmony’ with oneself, Günderrode maintains, is to achieve unity or harmony with others - or, to put it in terms of "Idea of the Earth", unity with the earth. ${ }^{33}$

It is thus not surprising that Günderrode goes on to claim that the goal of human moral activity - i.e., unity with oneself - is essential for the realization of the idea of the earth. Her point is not that I must be identical with myself alone, but rather that I must come to identify with the earth's "communal organism" and, in so doing, help realize the earth's vocation. She begins by noting that various moral ideals, including truth, justice, beauty, love, goodness and charity, are based on the idea of unity. Truth, for instance, "is the expression of what is always the same as itself”, while justice is the striving to achieve unity within diversity (GSW 2, 448). Beauty, in turn, is harmony, which is another name

32 Fichte, 'Some Lectures', 149; GA 6, $297 \mathrm{f}$.

33 While in "Idea of the Earth" Günderrode's focus is on the earth, the view that the moral vocation involves transforming one's self in order to become part of a larger community - without, however, annihilating one's individuality in order to achieve this unity - is present throughout her work. See Ezekiel 2014. 
for unity. In virtues such as love or charity, the goal is to understand and care for the other as one would for one's self - i. e., achieve a form of unity with the other. Importantly, Günderrode emphasizes, unity does not mean simple identity. Rather, unity involves connecting with what is beyond one's self, and as such implies difference and complexity. This is obvious in the cases of love and charity, where the goal is to care for the other as one would for one's self. However, it is also the case in truth, justice, goodness and beauty. Consider, for instance, the harmony that underpins beauty: harmony is not simple identity but unity in diversity. Similarly, justice involves the achievement of unity among different peoples, while truth is - again - the unity of different elements. Moral virtues, in other words, are only meaningful and relevant in relation with others, and, as Günderrode emphasizes in "Idea of the Earth", the other inhabitants of the earth. Accordingly, to speak of unity as a moral virtue, she contends, cannot mean unity with one's self, but rather unity with and through these others and the earth.

What does it take to realize these moral virtues? According to Günderrode, the individual must free itself from the "bonds of personality" in order to establish a real and vital harmony between itself and all beings on the earth and between itself and the earth (GSW 1, 449). Or as she puts it in "To Eusebio", virtue is "the forgetting of personality and particularity in favour of totality" (GSW 1, 361). In other words, to achieve unity with one's self, one must, first, achieve a deeper understanding of what the self is, i. e., recognize that the self is not isolated, but fundamentally relational. Second, one must act on this realization, i.e., transform one's ways of thinking and feeling, perceiving and understanding, in order to see unity and relationality in the place of difference and separation. Accordingly, unity with one's self is not unity or harmony with a pure I, but an 'extended' form of unity based on Günderrode's 'extended' conception of the self. Recognizing one's place in, and responsibility to, the earth and its community, and acting on this insight, is what Günderrode calls the 'realized idea of the earth'. She writes: "What is always one with itself, in harmony with itself, not torn into particularity [...] is that which I have referred to as the realized idea of the earth" (GSW 1, 449). In other words, the realized idea of the earth is the achievement of moral virtues (truth, justice, beauty and goodness) through unity not with oneself in the limited sense, but with oneself in an extended sense.

In this way, Günderrode regards the realization of the human vocation to depend on the transformation of oneself for the sake of the earth. This conception of human life and of the human vocation is made possible by the understanding of the self and nature she developed in her notes on Fichte. Precisely because the human being emerges in relation with others (the 'Whole'), the self is not alienated from the earth, but can only exist within it. The relationship between self and earth is thus re-configured: the earth does not exist for me, but I exist 
because of the earth. This does not imply, however, that the self is annihilated in its relation to the earth, i.e., that it becomes an unconscious member of an all-consuming whole. Rather, and as we have seen, for Günderrode the self is born out of this original relationality, such that the very possibility of the self depends upon the earth. In turn, our moral vocation does not consist in transforming the earth to align with our own ends, but rather in transforming ourselves so as to become better inhabitants of the earth. This is what she calls the "realization of the earth".

\section{Conclusion}

Günderrode offers a distinctive vision of our moral vocation and our relationship to the earth, one that can contribute to contemporary efforts to rethink the human-nature relation. Her claim that our usual ways of thinking and perceiving must be transformed for the sake of the earth prefigures the work of eco-feminist Val Plumwood, who argues that the environmental crisis is a 'crisis of reason', more specifically, of a reason that has failed to accommodate itself to the earth and its demands. ${ }^{34}$ In turn, Plumwood, like Günderrode before her, develops a relational account of the self, and contends that it is only if we conceive of ourselves in this way that we can begin to transform our relation to the earth and its inhabitants. ${ }^{35}$ Interestingly, Plumwood's critique of the Deep Ecology movement, advanced by Arne Næss and inspired by Spinoza, mirrors Günderrode's critique of Schelling's Spinozism: both Plumwood and Günderrode worry that the identification of self with nature (of freedom with natural necessity) tends to attenuate the distinctive moral responsibility that human beings bear to the natural world. $^{36}$

Günderrode's philosophy of nature might best be described as an attempt to understand the human being within nature without reducing human responsibility or diminishing difference. While her views clearly resonate with (and are influenced by) those of her contemporaries, they depart from them in important

34 As Plumwood argues, the first step in environmental ethics must involve transforming the way we think and perceive. Plumwood 1991, 59.

35 Plumwood invokes a "dialogical model of the self", and while she does not go into great detail, her account in many ways coheres with and is prefigured by Günderrode's expanded conception of the self. Cf. Plumwood 2002, 33.

36 See Plumwood 1991. 
and impressive ways. What we find in Günderrode's "Idea of the Earth" is a corrective to the view that German idealist and romantic philosophies of nature "virtually debunk" the notion of responsibility, ${ }^{37}$ and to the view that for the German romantics and idealists, the human relation to nature is one of either mastery or cultivation. Rather, Günderrode provides an account of the self and of human responsibility that articulates the complex human-nature relation in more productive ways: ways that can be brought to bear on contemporary environmental questions and concerns.

$\begin{array}{ll}\text { BdM } & \text { Fichte, J. G. Die Bestimmung des Menschen. Berlin, } 1800 . \\ \text { GA } & \text { Fichte, J. G. Gesamtausgabe der Bayerischen Akademie der Wissenschaften. } \\ & \text { Eds. R. Lauth et al. Stuttgart, 1962-. } \\ \text { GSW } & \text { Günderrode, K. von. Sämtliche Werke und ausgewählte Schriften. } \\ & \text { Ed. W. Morgenthaler. Frankfurt, 1990/91. } \\ \text { HKA } & \text { Schelling, F. W. J. Werke: Historisch-kritische Ausgabe. Ed. H. M. } \\ & \text { Baumgartner/G. Jacobs/H. Krings. Stuttgart-Bad Cannstatt, 1976-. } \\ \text { NS } & \text { Hardenberg, F. von. Novalis Schriften. Die Werke von Friedrich von Harden- } \\ & \text { berg. Eds. R. Samuel/H.-J. Mähl/P. Kluckhorn/G. Schultz. Stuttgart, 1960-88. } \\ \text { SFB } & \text { Schelling-Fichte Briefwechsel. Ed. H. Traub. Neuried, 2001. } \\ \text { 'Some Lectures' } & \text { Fichte, J. G. 'Some Lectures Concerning the Vocation of the Scholar'. In Fichte: } \\ & \text { Early Philosophical Writings. Ed./trans. D. Breazeale, 144-84. Ithaca, 1988. } \\ \text { SW } & \text { Schellings Sämtliche Werke. Ed. K. F. A. Schelling. Stuttgart, 1856-61. } \\ \text { VoM } & \text { Fichte, J. G. The Vocation of Man. Trans. W. Smith. Chicago, 1910. }\end{array}$

Arnim, B. von. 1986. Werke und Briefe, vol. 1. Ed. W. Schmitz. Frankfurt/M.

Beiser, F. C. 2002. German Idealism: The Struggle Against Subjectivism. Cambridge, MA.

-. 2003. The Romantic Imperative. Cambridge, MA.

Blumenbach, J. F. ${ }^{21789}$. Über den Bildungstrieb. Ed. J. C. Dieterich. Göttingen.

Breazeale, D./Rockmore, T. (eds.) 2013. Fichte's Vocation of Man: New Interpretive and Critical Essays. New York.

Christmann, R. 2005. Zwischen Identitätsgewinn und Bewußtseinsverlust. Das philosophischliterarische Werke der Karoline von Günderrode (1780-1806). Frankfurt.

Dormann, H. 2004. Die Kunst des inneren Sinns: Mythisierung der inneren und äußeren Natur im Werk Karoline von Günderrodes. Würzburg.

Ezekiel, A. C. (ed./trans.) 2016. “Introduction”. In Karoline von Günderrode: Poetic Fragments. Albany, 1-38.

-. (trans.) 2021. “Chapter 2. Günderrode”. In Women Philosophers in the Long Nineteenth Century: The German Tradition. Eds. D. Nassar/K. Gjesdal. New York/Oxford.

37 See Beiser, The Romantic Imperative, 186. 
-. 2014. “Metamorphosis, Personhood, and Power in Karoline von Günderrode”. European Romantic Review 25, 773-91.

Farr, A. 2013. “The Vocation of Postmodern Man: Why Fichte Now? Again!” In Breazeale/ Rockmore (eds.). Albany, 285-300.

Frank, M. 1997. 'Unendliche Annäherung'. Die Anfänge der philosophischen Frühromantik. Frankfurt.

Gardner, S. 2011. “Idealism and Naturalism in the Nineteenth Century.” In Stone (ed.) Edinburgh.

Hille, M. 1999. Karoline von Günderrode. Reinbeck.

Kosch, M. 2006. Freedom and Reason in Kant, Schelling and Kierkegaard. Oxford.

Mensch, J. 2013. Kant's Organicisim: Epigenesis and the Development of Critical Philosophy. Chicago.

Millán, E. 2013. 'Bestimmung as Bildung: On Reading Fichte’s vocation of Man as a Bildungsroman'. In Breazeale/Rockmore (eds.) 2013. Albany, 45-56.

Millán-Zaibert, E. 2005. “The Revival of Frühromantik in the Anglophone World”. Philosophy Today, Spring 2005, 96-117.

Morgenthaler, W. (ed.) 1990-1. Karoline von Günderrode: Sämtliche Werke und ausgewählte Studien. Frankfurt.

Nassar, D. 2013. The Romantic Absolute: Being and Knowing in Early German Romantic Philosophy, 1795-1804. Chicago.

Plumwood, V. 2002. Environmental Culture: The Ecological Crisis of Reason. London.

-. 1991. "Nature, Self, and Gender: Feminism, Environmental Philosophy and the Critique of Rationalism". Hypatia 6(1), 3-27.

Richards, R. 2002. The Romantic Conception of Life: Science and Philosophy in the Age of Goethe. Chicago.

Schleiermacher, F. 1893. On Religion: Speeches to its Cultured Despisers. Trans. J. Oman. London.

Singer, P. 1981. The Expanding Circle: Ethics and Sociobiology. Oxford.

Steigerwald, J. 2002. "Epistemologies of Rupture: The Problem of Nature in Schelling's Philosophy". Studies in Romanticism 42(4), 545-84.

Steinberg, M. “Knowledge Teaches Us Nothing: The Vocation of Man as Textual Initiation". In Fichte's Vocation of Man: New Interpretive and Critical Essays. New York, 57-78.

Stone, A. (ed.) 2011. The Edinburgh Critical History of Nineteenth-Century Philosophy. Edinburgh.

Tilliette, X. 2004. Schelling. Biographie. Stuttgart.

Westphal, W. 1993. Karoline von Günderrode und 'Naturdenken um 1800'. Essen.

Wolfe, C. T. 2014. "On the Role of Newtonian Analogies in Eighteenth-Century Life Science: Vitalism and Provisionally Inexplicable Explicative Devices". In Newton and Empiricism. Eds. Z. Biener/E. Schliesser. Oxford, 223-61. 